\title{
Analysis of Coordination degree on integrated transport system and economic development in Blue Economic Zone
}

\author{
MENG Xiangru, a, MENG Linghan ${ }^{2, \text { b }}$, ZHOU Caiyun ${ }^{1, c}$ \\ ${ }^{1}$ Shandong Jiaotong University, Jinan, Shandong province, China \\ ${ }^{2}$ Southwest Jiaotong University, Chengdu, Sichuan province, China

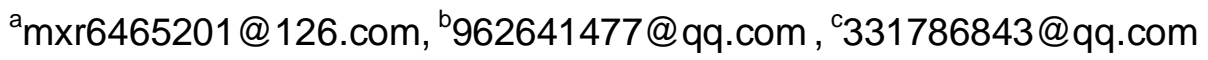

\begin{abstract}
Key words: Blue economic zone in Shandong peninsula, Integrated transport system, Economic development, Coordination degree, Analysis.

Abstract: Blue Economic Zone in Shandong Peninsula is the most dynamic and fastest-developing area with many advantageous resources and relatively advanced infrastructure in East China Shandong Province. The integrated transportation system and economic development has a close inner link, both are interdependent and influence each other. Based on the reference of the comprehensive transportation system, the paper focus on the analysis about transportation increase of gross domestic product, and studies Comprehensive transportation investment in fixed assets accounted for the proportion of total investment in fixed assets, and analyzes the elasticity coefficient on transport
\end{abstract}

The planning and development goals of the integrated transportation system in the Shandong Peninsula Blue Economic Zone

Transport equipment as well as economic efficiency differs in various modes of transport during the passenger and freight transportation. Therefore, comprehensive utilization of various transport modes can complete transportation tasks with less labor consumption by exploiting advantages of each mode.

Although competition exists among various modes of transport during their development, the overall trend is to form an integrated transportation system in which diverse modes of transport operate more coordinately, thus to optimize the transport structure and transportation management by properly planning and fully utilizing the advantage of each mode of transport with the goal of completing transportation tasks surely achieved. The Blue Economy includes marine exploration, utilization and protection as well as all related industries and social activities.

Therefore, we need to balance the infrastructure quantity in the integrated transportation system, optimize the transportation network, rationally allocate the resources, program better transportation chains and accelerate the construction of integrated transport hubs.

\section{Transportation increase of gross regional production in Shandong Peninsula}

The effect of transportation for economic growth gives expression to through the relationship between Gross regional production and transportation. The relationship between Gross regional production and transport can well reflect the role of integrated transportation system in the economy in Shandong province. Tab.1 reflects the relationship between gross regional production and transportation in Shandong province. 
Tab.1 Relations of gross regional production and transport development in Shandong province

\begin{tabular}{|l|c|c|c|c|c|c|}
\hline \multicolumn{1}{|c|}{ Grouping } & $\begin{array}{c}\text { In 2011 } \\
\text { (Million) }\end{array}$ & $\begin{array}{c}\text { In 2012 } \\
\text { (Million) }\end{array}$ & $\begin{array}{c}\text { In 2013 } \\
\text { (Million) }\end{array}$ & $\begin{array}{c}\% \text { of 2010 } \\
\text { in 2011 }\end{array}$ & $\begin{array}{c}\% \text { of 2011 in } \\
2012\end{array}$ & $\begin{array}{c}\% \text { of } 2012 \\
\text { in } 2013\end{array}$ \\
\hline Gross regional production & 45361.85 & 50013.24 & 54684.33 & 110.9 & 109.8 & 109.6 \\
\hline Tertiary industry & 17370.89 & 19995.81 & 22519.23 & 111.3 & 109.8 & 109.2 \\
\hline Transport industry & 2328.38 & 2516.19 & 2602.91 & 111.4 & 106.2 & 106.4 \\
\hline
\end{tabular}

Source: statistical yearbook of Shandong province

Tab. 1 shows the transportation and the development of economy has obvious alternation villa effect. Transportation industry is rapid development. From the point of transportation accounts for gross product, compared with 2010 in 2011 increased by $11.4 \%$. In 2012, increased by $6.2 \%$ in 2011. In 2013 than in 2012 increased by $6.4 \%$. Transport industry sustainable development.

\section{Transportation increase of gross regional production in Shandong Peninsula}

The development of the transportation industry is dependent on the fixed assets investment. Thus the construction of comprehensive transport system can be reflected through the investment in fixed assets. At the same time, the development on Shandong economic can also be reflected through the investment in fixed assets. There is an upward trend in fixed investment in Shandong province. Transportation industry was also increasing fixed assets investment. In recent years, the investment in fixed assets as shown in tableb.2 in Shandong province.

Tab.2 Investment in fixed assets table in Shandong province in 2009-2013

\begin{tabular}{|c|c|c|c|c|c|}
\hline year & 2009 & 2010 & 2011 & 2012 & 2013 \\
\hline overall investment & & & & 31255.96 & 36789.07 \\
( billion ) & 119030.97 & 23276.69 & 26769.73 & 15910010 & 19830961 \\
\hline $\begin{array}{c}\text { Transport investment } \\
\text { ( Million ) }\end{array}$ & 10180912 & 13388048 & 13956809 & & \\
\hline
\end{tabular}

Source: statistical yearbook of Shandong province

\section{The coefficient analysis of transport elasticity in Shandong Peninsula}

The ratio of growth rate on transport volume and the national economy is defined as a elasticity coefficient of transport. The elasticity coefficient of transport is used to reflect the proportion relationship between transportation and economic development in different period, the change characteristics and its parameters. The elasticity coefficient of transportation expressed in e. The elasticity coefficient of transport determined by two variables, namely the growth rate and economic growth. Relation of function constraint between them is: e= transport growth/economic growth. The growth index of freight and passenger traffic and freight turnover used to represent the transport rate. While economic growth is directly expressed in gross regional production. Different values of e reflect the different relationship between transportation and economic growth, specifically for: $\mathrm{e}<0$, Transportation is negatively related to the economic growth. $|\mathrm{e}|>1$ is the high elastic, transportation is growing faster than economic growth. Therefore economic growth greatly 
affects transportation, the transportation is very sensitive to changes in the economy. $|\mathrm{e}|<1$ is the low elasticity, Transport growth slower than economic growth. So it has a little influence on economic growth of transportation, the transportation is not sensitive to changes in the economy. From 2004 to 2012, the original data on passenger traffic, passenger turnover, freight volume and quantity as shown in table 3 and table 4 in Shandong province.

Tab.3 Passenger transport table in Shandong province in 2004-2012

\begin{tabular}{|l|l|l|l|l|l|l|l|l|}
\hline year & $\begin{array}{l}\text { Passenger } \\
\text { volume(ten } \\
\text { thousand } \\
\text { people })\end{array}$ & Railway & Highway & Waterway & $\begin{array}{c}\text { Turnover( } \\
\text { One } \\
\text { million } \\
\text { kilometers) }\end{array}$ & Railway & Highway & Waterway \\
\hline 2004 & 89388 & 3952 & 93178 & 1355 & 74799 & 28268 & 53910 & 600 \\
\hline 2005 & 98485 & 4757 & 103298 & 1417 & 82778 & 32223 & 60128 & 663 \\
\hline 2006 & 109472 & 5127 & 117309 & 1527 & 93014 & 34039 & 72022 & 818 \\
\hline 2007 & 123963 & 5470 & 205917 & 2000 & 106879 & 36694 & 104569 & 604 \\
\hline 2008 & 213387 & 5806 & 226134 & 2294 & 141867 & 37993 & 119723 & 997 \\
\hline 2009 & 234234 & 6041 & 240044 & 2635 & 158713 & 42135 & 121151 & 1185 \\
\hline 2010 & 248720 & 6609 & 241457 & 2403 & 164471 & 45872 & 125691 & 1188 \\
\hline 2011 & 250469 & 7650 & 254711 & 2574 & 172751 & 50951 & 130995 & 1250 \\
\hline 2012 & 264935 & 8484 & 258327 & 2580 & 183196 & 54995 & 133137 & 1153 \\
\hline
\end{tabular}

Source: statistical yearbook of Shandong province

Tab.4 Freight transport table in Shandong province in 2004-2013

\begin{tabular}{|c|c|c|c|c|c|c|c|}
\hline year & $\begin{array}{c}\text { freight } \\
\text { volume }\end{array}$ & Railway & Highway & Waterway & Turnover & Railway & Highway \\
\hline 2004 & 132036 & 17862 & 106887 & 7287 & 478309 & 111109 & 59606 \\
\hline 2005 & 147999 & 18338 & 120455 & 9206 & 558286 & 121908 & 71182 \\
\hline 2006 & 167511 & 19126 & 136750 & 11635 & 665521 & 151159 & 84510 \\
\hline 2007 & 198507 & 19923 & 163959 & 14625 & 642854 & 131151 & 106926 \\
\hline 2008 & 247489 & 20872 & 216604 & 10013 & 1010234 & 134133 & 511792 \\
\hline 2009 & 284463 & 19596 & 251587 & 13280 & 1095569 & 134139 & 604502 \\
\hline 2010 & 298055 & 18056 & 264366 & 15633 & 1174705 & 144775 & 621680 \\
\hline 2011 & 314962 & 19711 & 279380 & 15871 & 1258364 & 152606 & 662435 \\
\hline 2012 & 330270 & 19814 & 296752 & 13704 & 1099119 & 149384 & 705922 \\
\hline 2013 & 344401 & 19043 & 311812 & 13546 & 1026088 & 138910 & 749888 \\
\hline
\end{tabular}

Source: statistical yearbook of Shandong province

The elasticity coefficient of transportation is calculated by the index which use growth rate of 
Shandong integrated transport and gross regional production from 2005 to 2012. The elasticity coefficient of transportation as shown in Tab.5.

Tab.5 Transport elasticity coefficient table

\begin{tabular}{|c|c|c|c|c|c|c|c|c|c|}
\hline \multicolumn{2}{|c|}{$\begin{array}{c}\text { Mode of } \\
\text { transportation }\end{array}$} & 2005 & 2006 & 2007 & 2008 & 2009 & 2010 & 2011 & 2012 \\
\hline \multirow{3}{*}{$\begin{array}{c}\text { Freight } \\
\text { volume }\end{array}$} & Gross & 0.55 & 0.68 & 1.06 & 1.25 & 1.67 & 0.31 & 0.38 & 0.50 \\
\cline { 2 - 11 } & Railway & 0.14 & 0.21 & 0.22 & 0.25 & -0.67 & -0.50 & 0.56 & 0.10 \\
\cline { 2 - 11 } & Highway & 0.59 & 0.74 & 1.11 & 1.60 & 1.78 & 0.31 & 0.38 & 11.6 \\
\cline { 2 - 11 } & Waterway & 1.18 & 1.37 & 1.44 & -1.60 & 3.67 & 1.13 & 0.13 & -1.40 \\
\hline
\end{tabular}

\section{Summary}

Such as Tab.5, respectively with the total freight, rail freight, road freight, sea freight as transport growth index, and with gross regional production as an index of economic growth, can draw elasticity coefficient of railway freight transport is -0.67 and -0.50 in 2009 and 2010.The elasticity coefficient of waterway freight volume is -1.6 and -1.4 in 2008 and 2012, it shows negative correlation with integrated transport growth and economic growth in Shandong province. The elasticity coefficient of highway freight transport was 11.6 in 2012, more than 1 , for the high elasticity. It explains that road transport is growing faster than economic growth in 2012.So economic growth largely affects the road transportation. The highway transportation is sensitive to economic changes. The elasticity coefficient of railway freight transport was 0.1 in 2012 for the low elasticity. It declares that railway lags behind economic growth. It can not adapt to the requirements of economic development in Shandong province.

\section{Acknowledgment}

This paper is subsidized by the research project of Soft Science (2014RKB01942). in Sha ndong province.

\section{References}

[1]Christopher Kennedy.The Four Pillar of sustainable urban transportation[J].TransPort Review,2005,25(4):393-414.

[2]Wang Hongjiong, Li Shantong. Sustainable development and comprehensive transportation, Beijing: China railway publishing house, 1999.

[3]Ren Futian, Liu Xiaoming, Rong Jian. Traffic Engineering[M]. China Communications Press, 2008,7.

[4] Fred Osborn. City of Livermore Downtown parking study, Chapter VI :Parking Demand :shared parking[R],California :community planning department,2006.

[5]Peter Allen.A Sub-Regional Development Approach--Transport Intemational Trade 49 and Investment Modeled in Space[R]SSRN Working Paper,2001. 